Sains Malaysiana 50(4)(2021): 929-943

http://doi.org/10.17576/jsm-2021-5004-05

\title{
Teknologi Georuang dalam Analisis Potensi dan Pemetaan Risiko Tsunami di Pantai Barat Semenanjung Malaysia
}

(Geospatial Technology in Potential Analysis and Mapping of Tsunami Risk at West Coast Peninsular Malaysia)

\author{
Noor Suhaiza Sauti, Mohd Effendi Daud, Masiri KaAmin* \& NAJiHAH Remali
}

\section{ABSTRAK}

Gempa bumi yang berlaku pada 26 Disember 2004 telah mencetuskan gelombang tsunami terbesar menyebabkan limpahan tersebar di seluruh Lautan Hindi. Impaknya mengakibatkan kerosakan yang luas, kehilangan harta benda dan kehidupan terjejas di sepanjang pantai meliputi 12 negara di sepanjang Lautan Hindi. Kehilangan nyawa juga melibatkan rakyat dari 27 negara dari bahagian lain di dunia termasuklah di Malaysia terutamanya di pantai barat Semenanjung Malaysia. Kesignifikanan daripada bencana tsunami di Lautan Hindi ini, suatu tindakan persediaan dan mitigasi perlu dilaksanakan oleh pihak pengurusan bencana untuk menilai dan mengambil langkah yang bersesuaian untuk menangani dan mengurangkan risiko bencana tsunami. Kajian ini adalah untuk menganalisis potensi dan memetakan kawasan risiko tsunami di kawasan persisiran pantai barat Semenanjung Malaysia. Analisis potensi bahaya tsunami bagi penduduk di pantai barat Semenanjung Malaysia khususnya di Kota Kuala Muda, Kedah dilaksanakan menggunakan perisian Tsunami Display Program untuk memodelkan mekanisme pembentukan tsunami, perambatan gelombang dan tahap limpahan tsunami. Seterusnya bagi mengenal pasti risiko iaitu tahap kerentanan sesuatu kawasan terhadap bahaya tsunami, teknologi georuang diaplikasikan untuk menganalisis lokasi kawasan yang berbahaya dan selamat dengan mengambil kira faktor-faktor seperti guna tanah, jarak kawasan daripada persisiran pantai dan permukaan topografi atau kecerunan serta tinggi sesuatu kawasan. Fungsi tindihan lapisan dan pengelasan dalam teknologi georuang digunakan untuk mengelaskan kawasan kepada zon sangat bahaya, zon bahaya, zon sederhana dan zon selamat sekiranya berlaku tsunami. Hasil kajian ini mengenal pasti kawasan berpotensi terjejas selepas bencana iaitu Kampung Kuala Sungai Muda, Kampung Masjid, Kampung Kepala Jalan dan Kampung Padang Salin (Kampung Hujong Permatang) dengan purata jarak daripada garisan pantai kurang daripada $400 \mathrm{~m}$ serta peta kawasan berisiko berpandukan tahap kerentanan bencana tsunami di Kota Kuala Muda, Kedah. Sumbangan daripada kajian ini diharap dapat membantu pihak berkenaan dalam urusan persediaan, perancangan dan mitigasi bencana tsunami pada masa akan datang.

Kata kunci: Georuang; kerentanan; pemetaan; simulasi tsunami

\section{ABSTRACT}

An earthquake that occurred on December 26, 2004, triggered the most massive tsunami wave that spread over the entire Indian Ocean. The impacts of widespread damage have caused loss of property and impaired life along the coast covering 12 countries along the Indian Ocean. Loss of life has also involved people from 27 countries from other parts of the world including Malaysia especially on the west coast of Peninsular Malaysia. Significantly from the tsunami disaster in this Indian Ocean, a preparatory and mitigation action needs to be undertaken by disaster management to assess and take appropriate measures to address and mitigate the risks of the tsunami. This study is to analyze the potential and map the tsunami risk areas on the west coast of Peninsular Malaysia. The tsunami hazard analysis for residents on the west coast of Peninsular Malaysia especially in Kuala Muda City, Kedah was implemented using the Tsunami Display Program software to model the tsunami formation mechanism, wave propagation and tsunami overflow. Furthermore, to identify the risks of the vulnerability of an area to tsunami hazard, geospatial technology is applied to analyze the location of hazardous and safe areas by taking into account factors such as land use, distance from coastal and topographic or slope surfaces and elevated areas. Layer overlays and classification in geospatial technology are used to classify areas into extremely dangerous zones, hazard zones, moderate zones and safe zones in the event of a tsunami. The results of this study identified potential areas affected by the disasters such as Kampung Kuala Sungai Muda, Kampung Masjid, Kampung Kepala Jalan and Kampung Padang Salin (Kampung Hujong Permatang) with an average distance of fewer than $400 \mathrm{~m}$ of coastline and the map of hazardous areas based on the tsunami disaster susceptibility in Kota Kuala Muda, Kedah. Contributions from this study are expected to assist the stakeholders in preparing, planning and mitigating the tsunami disaster in the future.

Keywords: Geospatial; mapping; tsunami simulation; vulnerability 


\section{PENGENALAN}

Kejadian tsunami di Lautan Hindi yang berlaku pada 26 Disember 2004 telah memberi impak yang sangat buruk kepada manusia dan alam sekitar. Bencana alam ini telah mendapat liputan secara meluas oleh pihak media di seluruh dunia kerana ia merupakan bencana alam yang terburuk dalam sejarah ketamadunan manusia sejak 200 tahun terakhir (Chaturvedi et al. 2017). Bencana tsunami telah menyebabkan trauma di kalangan mangsa manakala kerajaan terpaksa mengeluarkan belanja yang besar untuk ganti rugi kerosakan dan pemulihan di samping menyediakan dana untuk penyelidikan berkaitan bencana alam ini sebagai langkah keselamatan pada masa akan datang. Walau bagaimanapun, tsunami merupakan bencana alam yang jarang berlaku dan perbelanjaan untuk persediaan tsunami hendaklah sepadan dengan kebarangkalian risiko yang dihadapi (Majlis Keselamatan Negara 2005).

Menurut Komoo (2005), kebarangkalian tercetusnya tsunami yang sama magnitud di sekitar lokasi yang sama dalam jangka masa beberapa dekad akan datang adalah rendah disebabkan oleh dua perkara: tempoh masa untuk tercetusnya gempa bumi jenis Sumatra di zon subduksi biasanya memakan masa 200 hingga 300 tahun; dan tsunami bertarikh 26 Disember 2004 adalah sangat kuat berikutan pelepasan tenaga tekanan yang terkumpul dalam tempoh masa yang lama dilepaskan secara tibatiba. Namun begitu, kemungkinan untuk berlakunya tsunami masih ada, berikutan gempa bumi yang berlaku di lokasi lain di sekitar Parit Subduksi Sunda (Sunda Subduction Trench). Menurut kajian Carayannis (2002), sekurang-kurangnya 10 runtuhan besar berlaku di dalam rantaian Pulau Canary bagi tempoh jutaan tahun dan dalam kitaran 10,000 tahun ataupun lebih dianggarkan runtuhan besar boleh berlaku. Secara asasnya, tsunami tidak boleh dicegah tetapi dengan ilmu pengetahuan berkaitan dengan formasi dan rembatan tsunami, kesan buruk akibat bencana ini boleh diminimakan (Papathoma et al. 2003). Reka bentuk strategi yang menjimatkan kos sebagai persediaan menghadapi tsunami perlu diambil kira berdasarkan kepada dua sifat tsunami iaitu pencetus tsunami dan kesannya (Hebenstreit 2001). Antara pencetus yang lazim berlaku ialah gempa bumi di dasar laut, letusan gunung berapi bawah lautan, gelinciran tanah di dasar laut dan hentaman meteorit, manakala gelombang tsunami adalah sama dengan gelombang pasang surut di garisan pantai (John \& Kathie 1997).

Penyepaduan komponen-komponen yang berasaskan sains dan manusia seperti tsunami-gempa bumi-siklon harus dipergiatkan dalam menghasilkan satu keputusan yang boleh diguna pakai dan dipraktikkan sebelum berlakunya tsunami, ketika berlakunya tsunami dan selepas berlakunya tsunami. Data daripada spektrum yang berbeza sama ada daripada satelit, sistem komunikasi dan juga internet adalah sangat penting dalam menangani kesemua fasa bahaya tersebut (Majlis Keselamatan Negara 2005).

Antara komponen yang perlu dipertimbangkan dalam perancangan pengurangan risiko dan kesan selepas bencana adalah seperti pengajian asasi, pengawasan dan sistem amaran, persediaan dan nilai risiko, dan langkahlangkah pemulihan (Papathoma et al. 2003). Pengajian asasi merangkumi pendidikan dan kesedaran awam mengenai bencana manakala pengawasan dan sistem amaran pula lebih tertumpu kepada ciri-ciri keselamatan yang telah disediakan di kawasan berisiko. Proses ini sangat rumit, namun dengan berbekalkan pelbagai set data berkenaan dengan bahaya tsunami sama ada secara berasingan dan gabungan, segala keperluan untuk menganalisis risiko bahaya tsunami sedia ada ini dapat dilaksanakan seperti yang dirancang.

Dewasa ini, pelbagai perisian yang diguna pakai dalam membantu manusia menguruskan sesuatu tugasan. Sistem Maklumat Geografi (GIS) adalah teknologi georuang yang terkenal dan mesra pengguna berkeupayaan untuk memaparkan maklumat spatial dan atribut mengikut lapisan demi lapisan dan memudahkan pengguna dalam menganalisa data dalam bentuk pertindihan, kuantiti dan sintesis dalam proses membuat keputusan (ESRI 2000). Teknologi ini direka bentuk untuk menyokong pengurusan bencana meliputi persediaan, mitigasi, tindak balas dan pemulihan selepas berlakunya bencana (Rantanen 1998; Van Westen 2013). Aplikasi GIS membolehkan taburan spatial kawasan berisiko bencana seperti ancaman tsunami dikenal pasti bagi menyediakan asas untuk dasar pengurangan risiko (Sauti et al. 2020).

Makalah ini menunjukkan kemampuan simulasi tsunami dengan Sistem Simulasi Tsunami dan permodelan analisis kerentanan tsunami menggunakan perisian teknologi georuang bagi menghasilkan satu keputusan berkaitan pengurusan bahaya tsunami. Antara manfaat yang diperoleh adalah dapat mengurangkan penggunaan peralatan canggih dan tenaga kerja mahir yang ramai dalam mengendalikan perisian teknologi georuang. Selain itu juga, ia boleh menggandakan produktiviti kemahiran juruteknik di samping boleh memberikan hasil yang berkualiti tinggi dan diiktiraf tanpa melibatkan kos yang tinggi. Ia boleh memudahkan proses membuat keputusan dan meningkatkan penyelarasan antara agensi apabila kecekapan adalah pada tahap optimum (Tomaszewski 2020).

Kesan bencana tsunami terhadap sesuatu lokasi adalah berbeza-beza dan ia bergantung kepada kekuatan magnitud gempa bumi, bentuk muka bumi dan juga lokasi 
pusat gempa. Faktor ini akan mempengaruhi halaju ombak, ketinggian ombak dan besarnya gelombang tsunami, masa yang diambil untuk sampai ke pantai, jarak dan keluasan kawasan (Paulatto et al. 2007). Matlamat kajian ini adalah mengaplikasikan teknologi georuang melalui pendekatan pembangunan pangkalan data serta paparan analisis untuk menghasilkan satu peta risiko tsunami. Bagi mencapai matlamat ini, kajian ini memfokuskan kepada analisis simulasi tsunami menggunakan perisian 'Tsunami Display Program'. Seterusnya untuk mengkaji risiko tsunami berdasarkan tiga unsur iaitu ketinggian, jarak dan juga guna tanah di kawasan yang terlibat dengan menggunakan teknologi georuang dan menghasilkan peta risiko bencana tsunami menggunakan perisian GIS.

Kajian ini menjurus kepada penganalisaan beberapa data spatial bagi menghasilkan satu peta yang telah dikelaskan kepada beberapa zon iaitu zon sangat bahaya, zon bahaya, zon sederhana dan juga zon selamat (Najihah et al. 2014). Perisian Arc GIS 10.1 digunakan untuk menyokong prosedur penganalisaan di samping perisian Tsunami Display Program yang digunakan untuk proses simulasi impak dan kejadian tsunami. Maklumat seperti ketinggian dan kecerunan lokasi sangat penting di samping maklumat lain seperti arah tsunami, jarak persisiran pantai, peta penempatan penduduk dan juga bentuk muka bumi.

Rajah 1 menunjukkan lokasi kawasan kajian yang telah dipilih iaitu Kota Kuala Muda, Kedah yang merupakan antara kawasan yang teruk terjejas oleh tsunami pada 26 Disember 2004. Daerah ini terletak di bahagian selatan Kedah, dipisahkan dengan Sungai Muda pada bahagian selatan manakala pada sebelah utara, bersempadan dengan daerah Bukit Mertajam, Pulau Pinang. Sejumlah lima buah kampung yang terletak di pesisir pantai iaitu Kampung Kuala Sungai Muda, Kampung Kepala Jalan, Kampung Masjid, Kampung Paya dan juga Kampung Pulau Sayak. Kawasan ini merekodkan kematian seramai 11 orang dan kecederaan kepada 27 orang penduduk (JPS 2005) di samping jumlah kerugian harta benda yang meliputi rumah penginapan, kenderaan, bot nelayan, jeti, peralatan menangkap ikan, sawah padi dan projek akuakultur yang dianggarkan sebanyak RM33.61 juta (Komoo 2005).

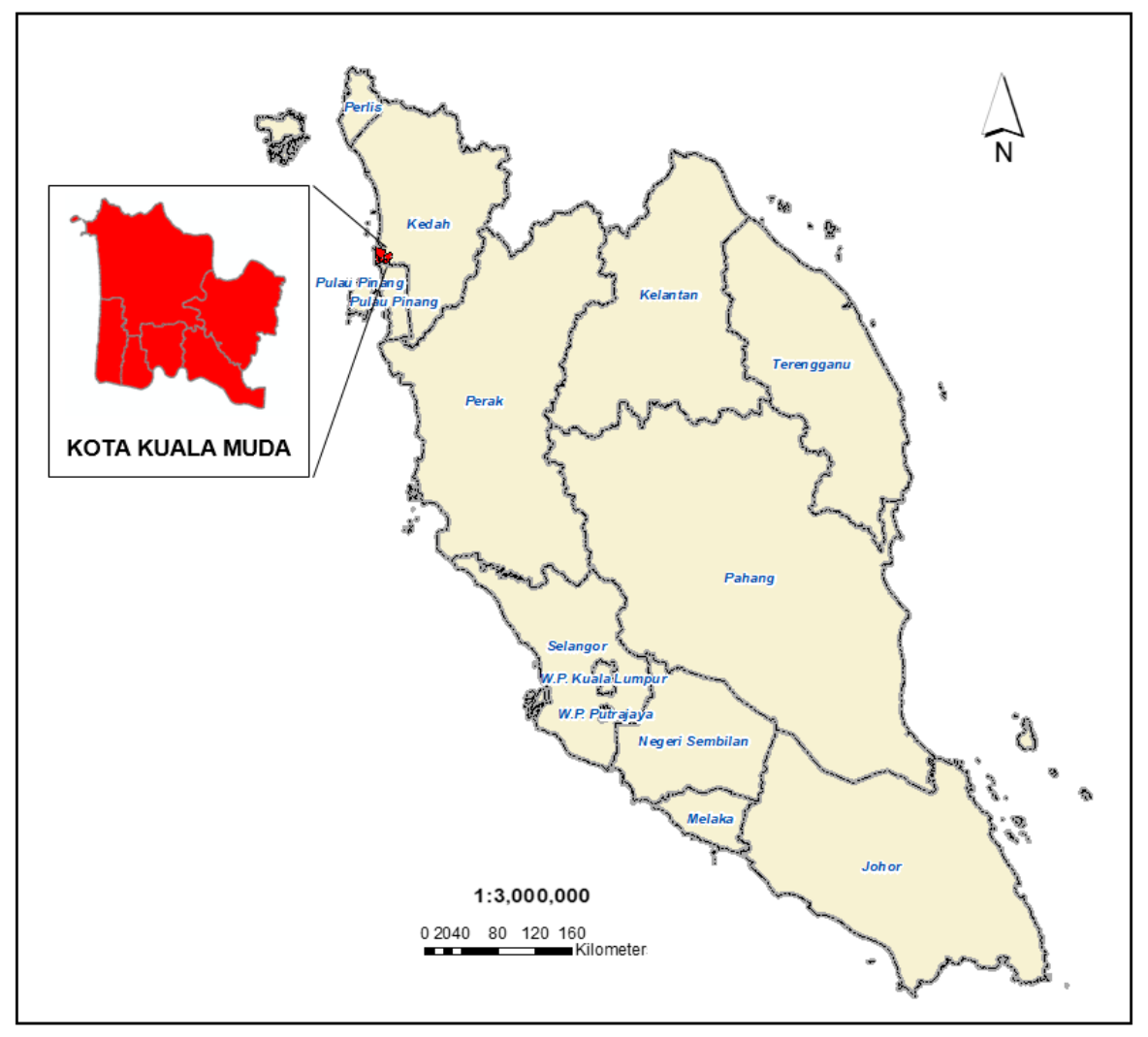

RAJAH 1. Kawasan kajian 


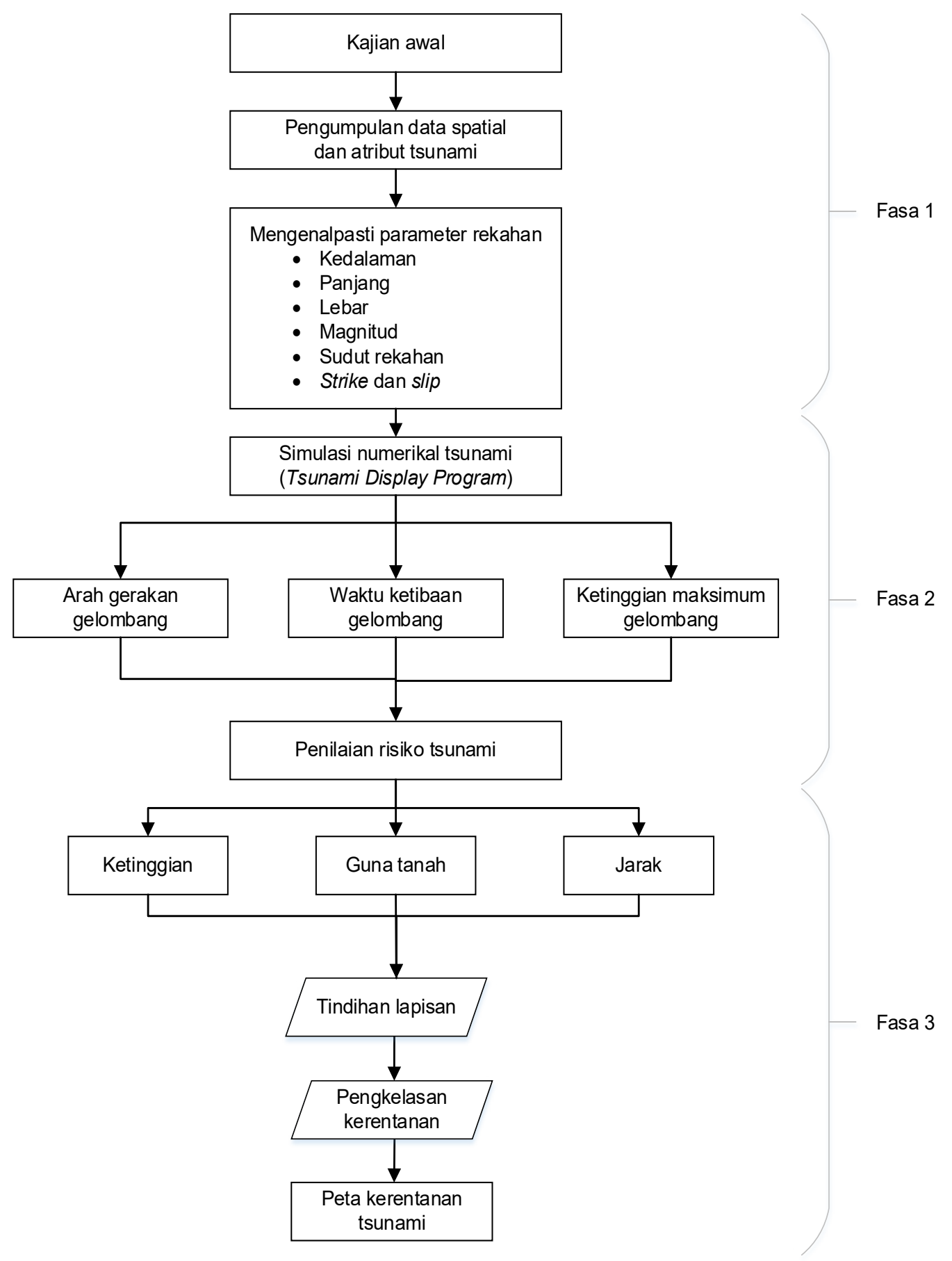

RAJAH 2. Carta alir fasa kajian 
Secara keseluruhannya, kajian ini terdiri daripada tiga fasa yang utama (Rajah 2). Fasa pertama, melibatkan kajian awalan berkenaan dengan kronologi kejadian tsunami pada 26 Disember 2004 dan kawasan yang terlibat. Kajian awal ini juga mengkaji tentang kesedaran dan kesan tsunami terhadap masyarakat setempat di Kota Kuala Muda. Fasa kedua melibatkan pemodelan berangka tsunami berdasarkan kepada parameter gempa bumi dan ciri-ciri tsunami yang terjadi pada 26 Disember 2004. Fasa ketiga, penghasilan peta kerentanan tsunami menggunakan pendekatan teknologi georuang.

\section{SIMULASI TSUNAMI}

Sistem simulasi berangka tsunami merupakan satu kaedah yang digunakan untuk merealisasi dan memberikan gambaran yang jelas mengenai perambatan gelombang tsunami yang terhasil daripada titik pusat gempa bumi, masa yang diambil untuk tiba di kawasan yang terlibat, ketinggian tsunami dan juga jarak inundasi (Cho et al. 2017; Watts et al. 2003). Pemantauan masa sebenar dan ketinggian ombak di lautan yang jauh dari pantai dapat membantu dalam mengurangkan kesan daripada bencana tsunami (Daud et al. 2008). Simulasi berangka tsunami biasanya dijalankan bagi menentukan potensi bahaya tsunami untuk sesebuah kawasan dan membantu dalam proses membuat keputusan untuk komuniti di kawasan tersebut. Mekanisma pembentukan tsunami, penyebaran dan tahap limpahan tsunami lebih difahami dengan simulasi model seterusnya membantu pihak pengurusan bencana untuk merencanakan sistem keselamatan di kawasan yang berpotensi dilanda tsunami (Teh et al. 2011). Masa ketibaan gelombang tsunami pertama yang direkodkan daripada sistem simulasi ini dapat membantu pihak berkuasa tempatan dan penduduk merancang dan bersedia untuk berpindah ke kawasan yang lebih selamat (Ismail et al. 2013). Ini dapat mengurangkan risiko tsunami terhadap kehilangan nyawa, meminimakan kos kerugian serta mengurangkan kesan kemusnahan terhadap alam sekitar.

\section{ANALISIS KERENTANAN TSUNAMI}

Secara amnya, kerentanan tsunami ditafsirkan sebagai keadaan yang terdedah kepada sebarang bahaya yang melibatkan manusia, alam sekitar, ekonomi dan juga memberi kesan terhadap emosi manusia (Aguirre-Ayerbe et al. 2018). Analisis kerentanan tsunami merupakan proses yang dijalankan bagi membuat penakrifan, mengenal pasti, membuat gambaran secara kuantiti, membuat pengkelasan dan mengenal pasti kelemahan dalam sistem.
Selain daripada itu, analisis ini mampu dalam membuat penilaian dan meramal keberkesanan langkah tersebut apabila diaplikasikan (Intergovernmental Oceanographic Commission 2009).

Menurut US Department of Energy (2002), setiap skala kerentanan adalah berbeza dan akan ditentukan mengikut jenis analisis yang dijalankan, sebagai contoh kajian risiko loji kuasa nuklear, sistem teknologi maklumat, tenaga dan sistem bekalan air, serta pengangkutan dan sistem perhubungan menggunakan skala yang berlainan antara satu sama lain. Berdasarkan kajian Dall'Osso et al. (2010), dengan adanya skala kerentanan tsunami bagi sesuatu kawasan yang berisiko, ia akan memudahkan pihak pengurusan dalam mengawal dan mengurus tadbir kawasan tersebut mengikut perancangan setelah mengambil kira faktor keselamatan, ekonomi dan juga peruntukan kewangan. Menurutnya lagi, sehingga kini masih belum ada nilai/indeks yang tepat untuk diguna pakai dalam kajian kerentanan tsunami, maka dalam menentukan jumlah keseluruhan kerentanan tsunami (Vtotal) dan beliau menggunakan kaedah intersection dalam perisian ArcGIS 10.1. Berikut merupakan persamaan yang digunakan, dengan pemberat dua kali ganda bagi kerentanan guna tanah (LUV) adalah mewakili nilai daya tahan dan juga aktiviti sosio-ekonomi untuk kawasan kajian.

$$
\text { Vtotal }=2 L U V+E V+D V
$$

dengan Vtotal ialah jumlah kerentanan; LUV ialah kerentanan guna tanah; $E V$ ialah kerentanan ketinggian; dan $D V$ ialah kerentanan jarak.

Secara keseluruhannya, penilaian kerentanan dan juga skala bagi setiap lokasi kajian adalah berlainan, bertepatan dengan situasi dan keadaan geologi kawasan. Ia juga dipengaruhi oleh sejarah bencana yang telah berlaku dengan penyelidik perlu mengambil kira faktor tersebut bagi mengadaptasi keputusan dengan keadaan sebenar. Ini mampu mengukuhkan lagi hasil kajian yang diperoleh.

\section{HASIL KAJIAN}

Hasil kajian yang diperoleh dipaparkan dalam bentuk jadual berserta rajah berkaitan. Jadual 1 memaparkan perbezaan waktu ketibaan tsunami daripada simulasi perisian GMT berbanding waktu ketibaan daripada kajian terdahulu. Nilai bagi parameter (panjang, lebar, kedalaman, strike, dip, slip, magnitud, latitud dan longitud) yang sama digunakan sebagai input untuk generasi simulasi tsunami. 
JADUAL 1. Perbandingan hasil yang diperoleh

\begin{tabular}{|c|c|c|c|c|c|}
\hline Parameter & & $\begin{array}{l}\text { Setyonegoro } \\
\text { (2011) }\end{array}$ & JPS (2005) & $\begin{array}{c}\text { Ismail et al. } \\
\text { (2013) (Model A) }\end{array}$ & $\begin{array}{l}\text { Ismail et al. } \\
\text { (2013) (Model B) }\end{array}$ \\
\hline \multirow[t]{2}{*}{ Panjang (km) } & $\mathrm{A} 1_{1}$ & 600 & - & 210 & 450 \\
\hline & $\mathrm{A} 1_{2}$ & 600 & - & 210 & 450 \\
\hline \multirow[t]{2}{*}{ Lebar (km) } & $\mathrm{Aw}_{1}$ & 75 & - & 120 & 190 \\
\hline & $\mathrm{Aw}_{2}$ & 0 & - & 0 & 0 \\
\hline \multicolumn{2}{|c|}{ Kedalaman (km) } & 10 & - & 10 & 25 \\
\hline \multicolumn{2}{|l|}{ Strike (Darjah) } & 345 & - & 324 & 325 \\
\hline \multicolumn{2}{|l|}{ Dip (Darjah) } & 15 & - & 10 & 8 \\
\hline \multicolumn{2}{|l|}{ Slip $(\mathrm{m})$} & 15 & - & 110 & 110 \\
\hline \multicolumn{2}{|l|}{$\begin{array}{l}\text { Magnitud } \\
\text { (Ritcher) }\end{array}$} & 9.2 & - & 9.2 & 7.3 \\
\hline \multirow{2}{*}{ Kedudukan sesa } & Latitud & 5.50 & - & 1.34 & 2.02 \\
\hline & Longitud & 93.85 & - & 95.21 & 94.89 \\
\hline \multicolumn{2}{|c|}{ Waktu Ketibaan (min) } & $\begin{array}{c}165 \\
(\text { Malaysia N) }\end{array}$ & $\begin{array}{c}285 \\
\text { (Kuala Muda) }\end{array}$ & $\begin{array}{c}280 \\
\text { (Kuala Muda) }\end{array}$ & $\begin{array}{c}275 \\
\text { (Kuala Muda) }\end{array}$ \\
\hline \multicolumn{2}{|c|}{ Waktu Ketibaan Tsunami Display } & $\begin{array}{c}200 \\
\text { (Kota Kuala } \\
\text { Muda) }\end{array}$ & & $\begin{array}{c}240 \\
\text { (Kuala Muda) }\end{array}$ & $\begin{array}{c}220 \\
\text { (Kuala Muda) }\end{array}$ \\
\hline \multicolumn{2}{|c|}{ Perbezaan waktu (min) } & 35 & - & 40 & 55 \\
\hline
\end{tabular}

Bagi menjalankan simulasi tsunami, beberapa sumber utama dikenal pasti iaitu lokasi titik pusat gempa, batimetri (topografi dasar laut), parameter gempa bumi, sejarah gempa bumi terdahulu dan beberapa faktor lain. Jadual 2 menunjukkan maklumat lokasi yang dipilih di sekitar Lautan Hindi bagi menjalankan simulasi tsunami.

JADUAL 2. Lokasi titik sumber bagi simulasi tsunami yang ditetapkan

\begin{tabular}{cccc}
\hline Lokasi & Latitud & Longitud & $\begin{array}{c}\text { Jarak pusat gempa ke } \\
\text { kawasan kajian }\end{array}$ \\
\hline 1 & 5.10 & 97.75 & 294 \\
2 & 5.05 & 94.74 & 631 \\
3 & 6.40 & 92.62 & 855 \\
4 & 8.95 & 92.34 & 953 \\
5 & 10.25 & 93.00 & 967 \\
\hline
\end{tabular}


Rajah 3 dan 4 menunjukkan paparan imej yang dihasilkan daripada simulasi tsunami yang dijalankan di beberapa lokasi terpilih di kawasan kajian. Rajah 3(a) \& 3(b) merupakan paparan hasil simulasi perambatan gelombang tsunami yang dijanakan di lokasi gempa bumi 1 pada skala Richter 7.5. dan 9.0. Warna merah dan biru dalam paparan gelombang tsunami adalah mewakili kedalaman batimetri lautan. Setiap paparan imej memaparkan waktu ketibaan gelombang, ketinggian gelombang dan juga kedudukan pusat gempa. Berdasarkan simulasi yang diperoleh, didapati corak perambatan gelombang tsunami dan halajunya adalah berbeza ketika melalui Lautan Hindi dan Selat Melaka.

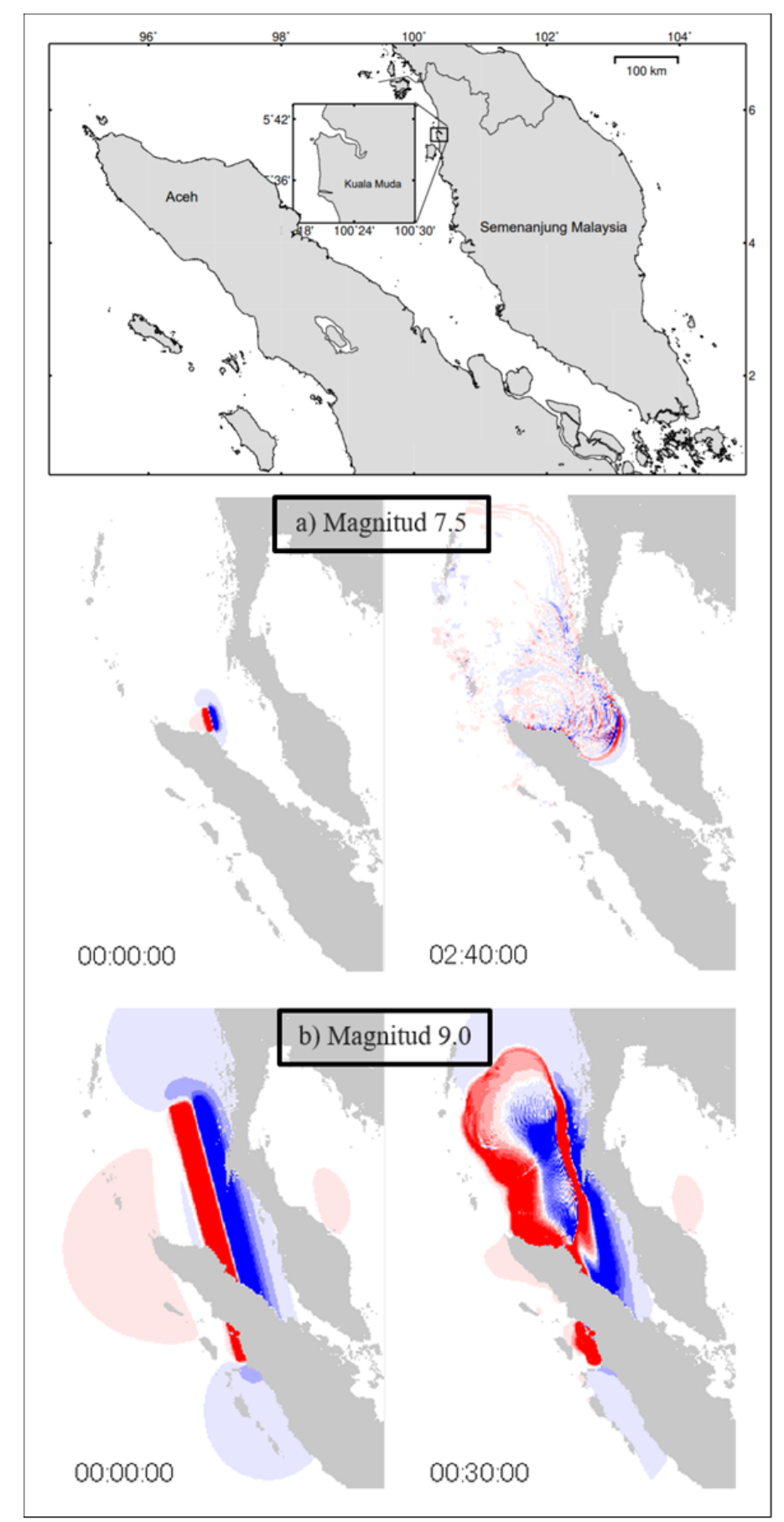

RAJAH 3. Paparan lokasi kawasan kajian dan simulasi tsunami di lokasi 1 


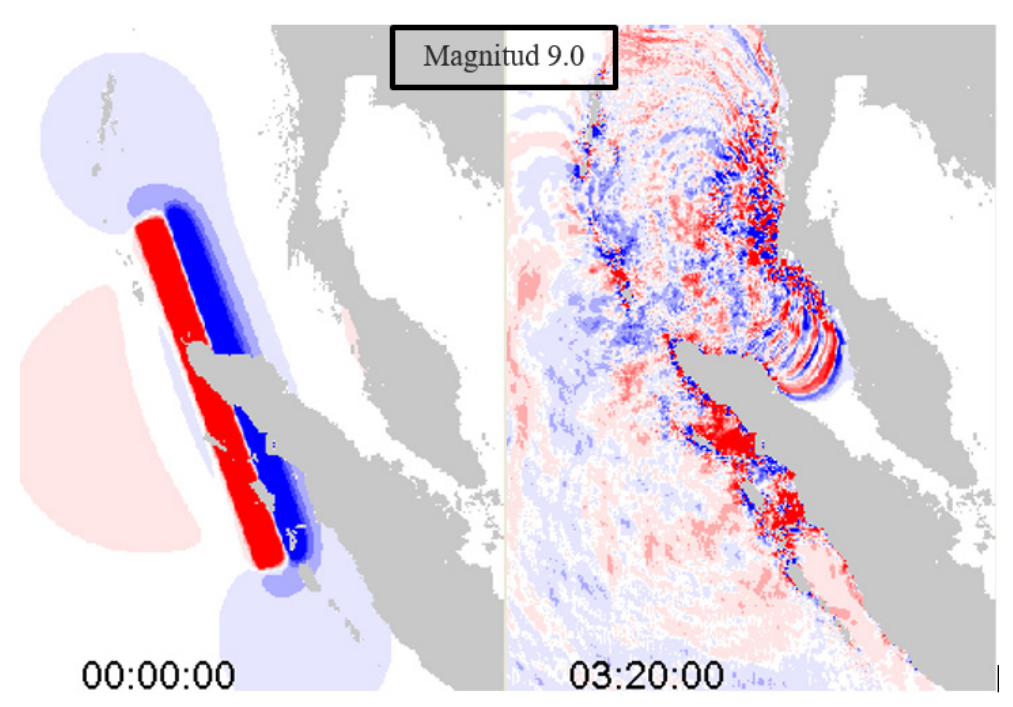

RAJAH 4. Paparan simulasi tsunami 26 Disember 2004

Rajah 4 merupakan paparan hasil simulasi perambatan gelombang tsunami di lokasi gempa bumi pada tahun 2004 (gempa bumi Aceh). Perubahan perambatan gelombang tsunami ini disebabkan oleh perbezaan batimetri yang ketara antara Lautan Hindi dan Selat Melaka. Hasil daripada proses simulasi ditunjukkan dalam Jadual 3.

JADUAL 3. Waktu ketibaan gelombang untuk setiap lokasi titik pusat gempa yang ditetapkan

\begin{tabular}{|c|c|c|c|c|}
\hline Lokasi & Magnitud & $\begin{array}{c}\text { Jarak }(\mathrm{km}) \\
\text { (dari titik pusat) }\end{array}$ & Waktu ketibaan (min) & $\begin{array}{l}\text { Ketinggian maksimum } \\
(\mathrm{m})\end{array}$ \\
\hline \multirow{2}{*}{1} & 9.0 & \multirow{2}{*}{294} & 30 & 11 \\
\hline & 7.5 & & 160 & 6 \\
\hline \multirow{2}{*}{2} & 9.0 & \multirow{2}{*}{631} & 195 & 11 \\
\hline & 7.5 & & 240 & 6 \\
\hline \multirow{2}{*}{3} & 9.0 & \multirow{2}{*}{855} & 200 & 11 \\
\hline & 7.5 & & 255 & 6 \\
\hline \multirow{2}{*}{4} & 9.0 & \multirow{2}{*}{953} & 210 & 11 \\
\hline & 7.5 & & 290 & 6 \\
\hline \multirow{2}{*}{5} & 9.0 & \multirow{2}{*}{967} & 230 & 11 \\
\hline & 7.5 & & 300 & 6 \\
\hline T2004 & 9.0 & 590 & 200 & 11 \\
\hline
\end{tabular}


Hasil keseluruhan waktu gelombang tiba di setiap lokasi dipaparkan dalam perisian Generic Mapping Tool (GMT) (Rajah 5). Seterusnya, keadaan topografi kawasan kajian dikenal pasti menggunakan data Shuttle Radar
Topography Mission (SRTM) berketepatan $90 \mathrm{~m}$. Data SRTM merupakan data digital bagi ketinggian muka bumi untuk menghasilkan kontur dan kecerunan kawasan kajian.

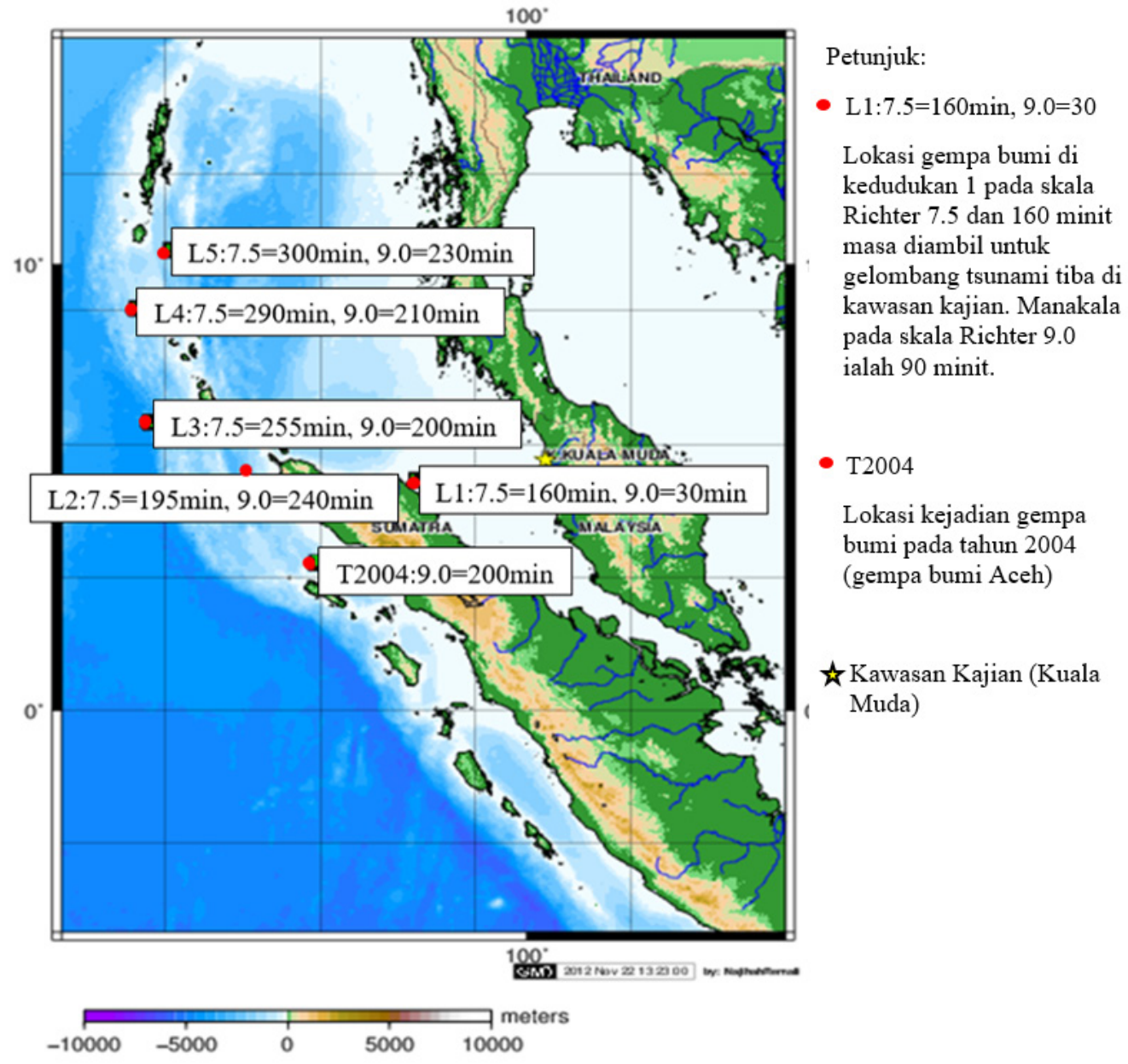

RAJAH 5. Waktu ketibaan gelombang untuk setiap lokasi

Taburan guna tanah di kawasan kajian ditunjukkan dalam Rajah 6. Pada peringkat ini, guna tanah semasa bagi kawasan Kota Kuala Muda, Kedah dikenal pasti berdasarkan data dan maklumat daripada Pihak Berkuasa Tempatan serta peta guna tanah bagi tahun 2000 yang diperoleh daripada Jabatan Ukur dan Pemetaan (JUPEM) Negeri Kedah. Kebanyakan guna tanah di kawasan ini terdiri daripada sistem perparitan, pertanian, hutan, penempatan, dan juga kawasan berair (berpaya) (Jadual 4). 


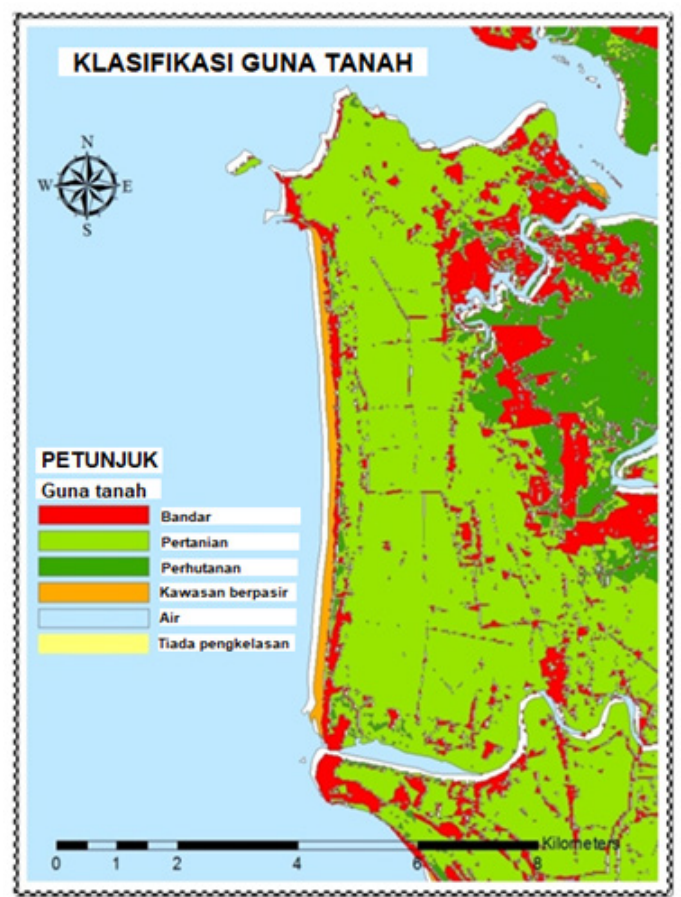

RAJAH 6. Taburan pengkelasan guna tanah di kawasan kajian (Sumber dari peta guna tanah daerah Kuala Muda, 2000)

JADUAL 4. Pengelasan guna tanah (Dall'Osso et al. 2010)

\begin{tabular}{lc}
\hline Guna tanah & Kelas/Skor \\
\hline Kawasan penempatan (kepadatan tinggi) & Sangat berisiko (5) \\
Kawasan penempatan (kepadatan rendah) & Berisiko (4) \\
Pertanian, pantai, kolam ternakan, tasik dan sungai & Sederhana (2) \\
Hutan dan paya bakau & Sangat kurang berisiko (1) \\
\hline
\end{tabular}

Analisis penimbal digunakan untuk menentukan kelas dan skor jarak kawasan daripada garisan pantai (Jadual
5). Peta risiko berdasarkan jarak daripada garisan pantai dipaparkan dalam Rajah 7.

JADUAL 5. Kelas dan skor untuk jarak daripada garisan pantai (Dall'Osso et al. 2010)

\begin{tabular}{cc}
\hline Jarak daripada garisan pantai $(\mathrm{m})$ & Kelas/Skor \\
\hline $0-100$ & Sangat tinggi (5) \\
$100-200$ & Tinggi (4) \\
$200-300$ & Sederhana (3) \\
$300-400$ & Rendah (2) \\
$400-500$ & Sangat rendah (1) \\
\hline
\end{tabular}




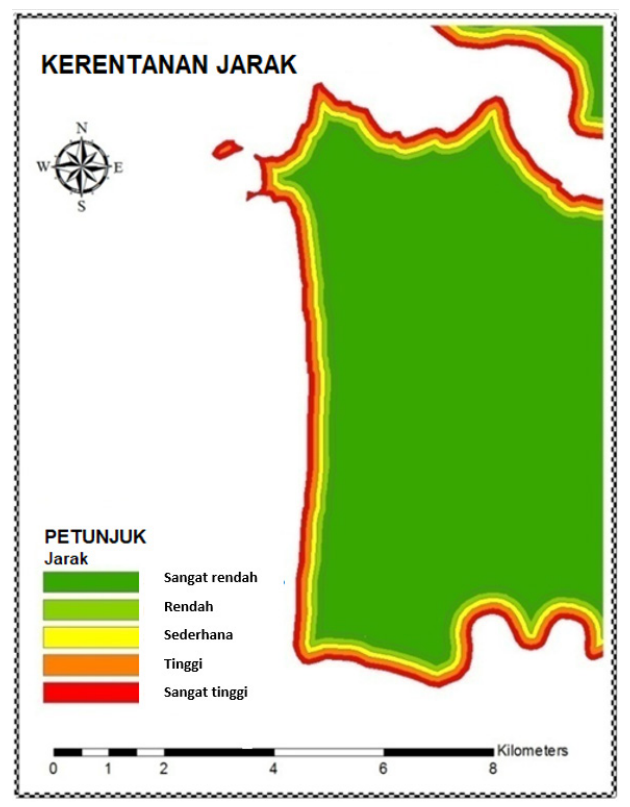

RAJAH 7. Peta kerentanan jarak

Analisis ketinggian topografi juga penting dalam menghasilkan peta risiko tsunami kerana tsunami biasanya melanda kawasan yang bertopografi rendah. Oleh itu, bagi mendapatkan topografi kawasan kajian, data satelit berketepatan $90 \mathrm{~m}$ iaitu SRTM digunakan Ketinggian kawasan dikelaskan kepada 5 kategori merujuk kepada penyelidikan yang dijalankan oleh Dall'Osso et al. (2010) (Jadual 6).

JADUAL 6. Kelas dan skor risiko berdasarkan ketinggian kawasan (Dall’Osso et al. 2010)

\begin{tabular}{cc}
\hline Ketinggian kawasan $(\mathrm{m})$ & Kelas/Skor \\
\hline $0-5$ & Sangat tinggi (5) \\
$5-10$ & Tinggi (4) \\
$10-15$ & Sederhana (3) \\
$15-20$ & Rendah (2) \\
$>20$ & Sangat rendah (1) \\
\hline
\end{tabular}

Rajah 8 menggambarkan taburan spatial kawasan berisiko mengikut kategori berdasarkan ketinggian kawasan.

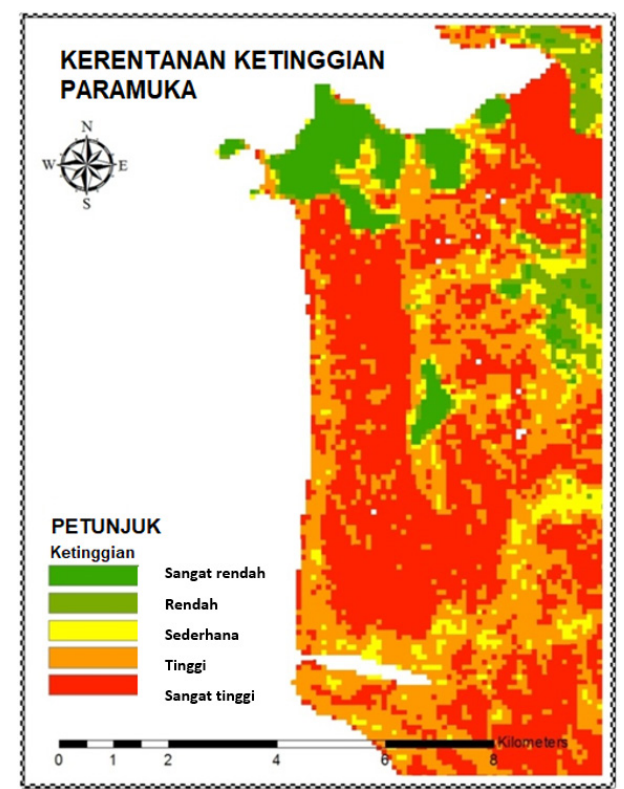

RAJAH 8. Peta kerentanan ketinggian 
Penggabungan ketiga-tiga analisis ini menggunakan menu intersect dalam perisian ARCGIS untuk mendapatkan nilai keseluruhan skor bagi menentukan zon untuk setiap kawasan. Pembahagian zon dibahagikan kepada empat kelas seperti dalam Jadual 7.

JADUAL 7. Jumlah skor dan zon bagi keseluruhan analisis adaptasi daripada Dall'Osso et al. (2010)

\begin{tabular}{lc}
\hline Jumlah skor & Zon \\
\hline $12-15$ & Sangat bahaya \\
$9-11$ & Bahaya \\
$6-8$ & Sederhana \\
$3-5$ & Selamat \\
\hline
\end{tabular}

Secara keseluruhannya, gabungan daripada unsur risiko iaitu kerentanan guna tanah, jarak dari garisan pantai dan ketinggian kawasan adalah penghasilan peta risiko tsunami menggunakan fungsi tindihan lapisan dalam perisian ArcGIS 10.1 (Rajah 9).

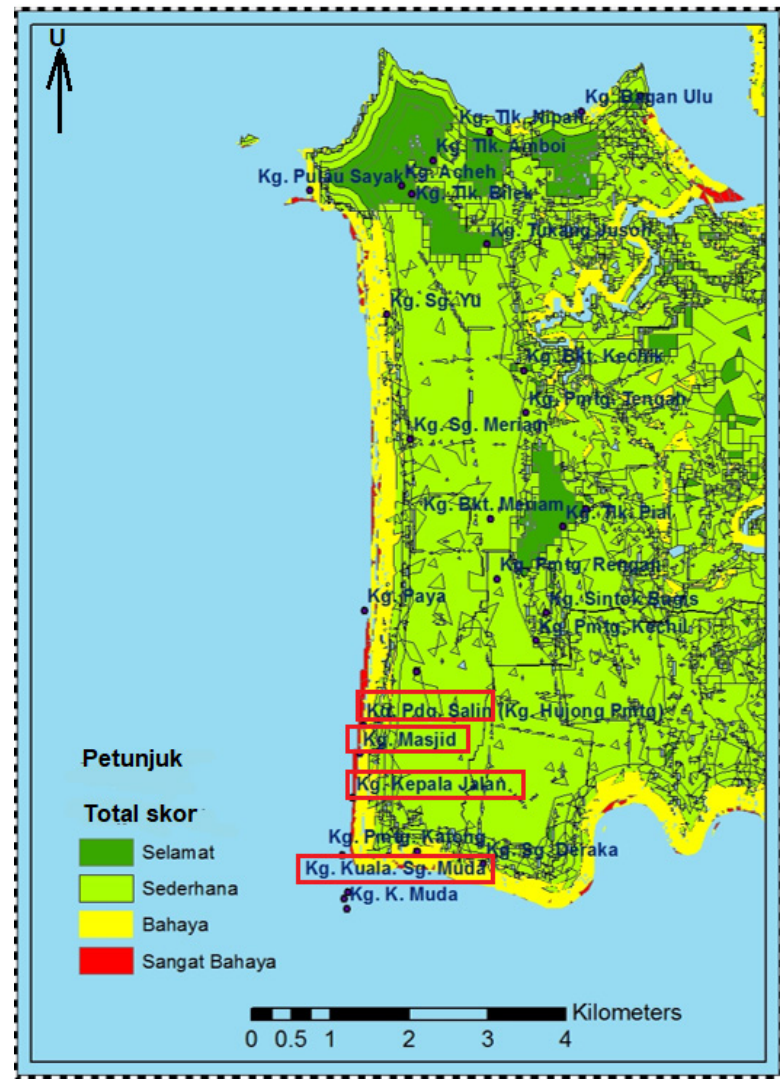

RAJAH 9. Peta risiko kerentanan tsunami 


\section{PERBINCANGAN}

Hasil kajian yang diperoleh pada fasa 1 iaitu di peringkat kajian awal, sangat membantu dalam merealisasikan fasa 2 dan fasa 3. Ini adalah kerana fasa tersebut memberikan banyak maklumat berkenaan dengan sejarah tsunami pada tahun 2004 dan memahami situasi sebenar di kawasan kajian ketika bencana tersebut melanda. Pada fasa ini, temu ramah dan soal selidik dijalankan bersama penduduk kampung dan juga agensi yang terlibat seperti Majlis Keselamatan Negara, Jabatan Pengairan dan Saliran (JPS) Negeri Kedah dan Pejabat Daerah untuk mendapatkan maklumat lanjut berkaitan bencana tersebut. Hasil daripada fasa ini merupakan rentetan kepada kajian seterusnya bagi mengetahui sejauh mana keperluan dan kepentingan kajian ini di kawasan tersebut.

Daripada analisis simulasi berangka tsunami di fasa 2 kajian pula, dapat dirumuskan bahawa parameter yang digunakan dalam kajian terdahulu (Setyonegoro 2011) adalah menepati ciri-ciri parameter gempa bumi dan tsunami setelah dibuat perbandingan dengan parameter yang dikeluarkan oleh pihak United States Geological Survey (USGS 2012). Daripada kajian ini, model bagi sumber pertama iaitu gempa yang berlaku pada 2004 menunjukkan tempoh masa untuk tsunami tiba di pesisir pantai adalah dalam tempoh lebih kurang 4 jam. Ini selari dengan laporan USGS yang menunjukkan tempoh masa tsunami tiba di Kota Kuala Muda, Kedah adalah dalam lingkungan 4 jam. Namun begitu, terdapat perbezaan antara setiap model seperti yang tercatat di Jadual 1 memandangkan setiap penyelidik menggunakan perisian permodelan yang berbeza.

Melalui kajian ini, didapati bahawa kaedah pemodelan berangka adalah salah satu cara untuk mengetahui corak perambatan tsunami secara praktik (Najihah et al. 2014). Kaedah ini dapat membantu perancangan dan persediaan untuk menghadapi kemungkinan berlaku tsunami pada masa akan datang. Ia jelas terbukti berkesan kerana kaedah ini telah diaplikasikan di negara yang berisiko tinggi diancam tsunami seperti Jepun dan juga Indonesia. Hasil simulasi jelas membantu penduduk dan pihak berkuasa dalam membuat persediaan menghadapi bencana gempa bumi dan tsunami pada masa akan datang.

Bagi hasil kajian untuk fasa 3 pula, ia merujuk kepada pemetaan kawasan terdedah kepada bahaya tsunami di Kota Kuala Muda, Kedah pada 2004 dihasilkan melalui gabungan tiga unsur peta iaitu topografi kawasan, jarak selamat serta peta guna tanah kawasan tersebut. Unsur peta ini turut digabungkan dengan peta kawasan yang merangkumi nama kampung dan juga mukim kawasan.

Pemetaan kawasan berisiko terhadap bencana tsunami ini dikelaskan kepada 4 jenis zon iaitu zon sangat bahaya, zon bahaya, zon sederhana dan juga zon selamat. Pengkelasan zon adalah bergantung kepada tiga kriteria utama iaitu berdasarkan jarak kawasan yang terdedah kepada bahaya tsunami daripada garis pantai (shoreline), keadaan topografi (ketinggian) kawasan yang terdedah kepada bahaya tsunami serta berdasarkan faktor guna tanah (kepadatan penduduk). Pengkelasan zon bahaya dengan zon sangat bahaya dipengaruhi oleh perubahan ketara faktor guna tanah, topografi (ketinggian kawasan) dan jarak daripada garis pantai. Mengikut laporan bencana oleh JPS pada tahun 2005 dan kajian awalan, didapati kawasan yang terjejas teruk akibat tsunami pada tahun 2004 adalah kawasan yang berjarak kurang daripada 200 $\mathrm{m}$ dari garis pantai serta ketinggian kawasan yang berjarak kurang $200 \mathrm{~m}$ adalah dalam julat 1 hingga $6 \mathrm{~m}$ daripada aras purata laut berbanding ketinggian gelombang tsunami adalah 6 hingga $11 \mathrm{~m}$. Berdasarkan Rajah 9, didapati terdapat sekurang-kurangnya empat buah kampung yang dikategorikan sangat bahaya risiko tsunami iaitu Kampung Kuala Sungai Muda, Kampung Masjid, Kampung Kepala Jalan dan Kampung Padang Salin (Kampung Hujong Permatang). Berdasarkan skor atau kriteria yang diguna pakai dalam menghasilkan peta risiko kerentanan tsunami dengan kriteria utama ialah jarak daripada garis pantai ( $0-150 \mathrm{~m})$ adalah sangat bahaya. Kawasan yang berada dalam lingkungan jarak tersebut, didapati mempunyai faktor guna tanah sangat tinggi (kepadatan penduduk) berbanding dengan kawasan yang berjarak lebih daripada $200 \mathrm{~m}$ daripada garis pantai. Di samping itu juga, faktor topografi (ketinggian) di kawasan tersebut adalah sangat rendah iaitu ketinggian dari aras purata laut dalam julat 1 hingga $6 \mathrm{~m}$ sahaja. Hasil simulasi tsunami di lima lokasi terpilih menunjukkan purata ketinggian maksimum tsunami di kawasan tersebut adalah dalam julat 6 hingga $11 \mathrm{~m}$ bergantung kepada saiz gempa bumi. Peta risiko kerentanan tsunami yang dihasilkan adalah bertepatan dengan laporan bencana yang dibuat oleh JPS pada tahun 2005. Sementara itu, empat buah kampung yang berada di dalam zon bahaya dengan nilai bacaan kerentanan antara 9 hingga 11 adalah terdiri daripada Kampung Permatang Katong, Kampung Sungai Yu, Kampung Pulau Sayak dan juga Kampung Teluk Nipah yang mempunyai purata jarak daripada garisan pantai kurang daripada $400 \mathrm{~m}$.

Jika dibandingkan dengan kajian yang dijalankan oleh Sinaga et al. (2011), kajian ini tidak mengambil kira faktor kawasan terdedah berdasarkan arah relatif gelombang memandangkan 85 peratus kawasan sepanjang pesisir pantai di Kota Kuala Muda merupakan kawasan teluk yang berada di kedudukan sangat tinggi dalam parameter risiko tsunami.

Secara keseluruhan, tsunami 2004 telah memberikan impak yang besar bagi kawasan Kota Kuala Muda, Kedah dan mendorong kajian ini untuk menghasilkan sebuah peta kawasan terdedah bahaya tsunami Kota Kuala Muda, Kedah. Kesemua analisis dalam fasa ketiga 
mengaplikasikan teknologi georuang bagi memenuhi kehendak dan objektif kajian. Teknologi ini sangat membantu dari segi kerja pembangunan pangkalan data dan pemprosesan data seterusnya memudahkan proses penghasilan peta risiko tsunami. Melalui peta yang dihasilkan, kawasan yang terdedah kepada bahaya tsunami dan kawasan yang selamat daripada bahaya tsunami dapat dikenal pasti. Berdasarkan empat zon yang dikenal pasti, sempadan bagi kawasan selamat dapat ditentukan berdasarkan jarak selamat iaitu jarak lebih 500 m daripada garisan pantai.

Seterusnya, kajian ini dijangka dapat membantu penduduk di kawasan yang berisiko untuk menghadapi segala kemungkinan dan melengkapkan diri dengan pengetahuan mengenai perkara yang harus dilakukan jika bencana tersebut berlaku. Sebagai contoh, sekiranya amaran tsunami dikeluarkan oleh pihak berkuasa, penduduk perlu bersedia dan mengambil tindakan yang sewajarnya seperti berpindah ke kawasan yang telah dikelaskan sebagai zon selamat (hasil daripada simulasi berangka tsunami) dalam tempoh masa yang telah diberikan.

\section{KESIMPULAN}

Secara umumnya, kajian ini telah mewujudkan satu aplikasi pengurusan dan sistem amaran menghadapi bencana tsunami pada masa akan datang bagi kawasan yang terlibat. Kajian ini juga mengaplikasikan teknologi georuang dalam menganalisis data dan menghasilkan peta risiko kerentanan tsunami di Kota Kuala Muda, Kedah. Peta yang dihasilkan mengambil kira empat faktor utama iaitu, ketibaan (masa) dan ketinggian gelombang tsunami. Berdasarkan simulasi yang diperoleh, didapati corak perambatan gelombang tsunami dan halajunya adalah berbeza ketika melalui Lautan Hindi dan Selat Melaka. Perubahan perambatan gelombang tsunami ini disebabkan oleh perbezaan batimetri (bathymetry) yang ketara antara Lautan Hindi dan Selat Melaka iaitu kedalaman lautan di Lautan Hindi adalah tiga kali ganda berbanding dengan kedalaman lautan di Selat Melaka.

Oleh itu, perubahan perambatan gelombang yang terjadi di Lautan Hindi dan Selat Melaka yang dihasilkan daripada simulasi ini amat bertepatan dengan teori dan ciri-ciri gelombang tsunami. Gelombang tsunami akan bergerak dengan halaju yang tinggi di lautan yang dalam dan sebaliknya apabila gelombang tsunami melalui kawasan kedalaman yang cetek. Bagi simulasi pertama, gelombang pertama menghentam persisiran pantai Kota Kuala Muda adalah pada min ke 150 atau mengambil masa selama 2 jam 30 min selepas berlakunya gempa bumi di Lokasi 1 diikuti pula dengan Lokasi 2 yang mengambil masa selama 240 min, Lokasi 3 selama 230 min, Lokasi 4 selama 240 min dan lokasi terakhir iaitu Lokasi 5 mengambil masa selama 260 min. Di samping itu juga, faktor kedalaman turut mempengaruhi ketinggian gelombang tsunami dengan ketinggian gelombang tsunami akan meningkat dengan amat ketara di kawasan yang kedalamannya cetek.

Faktor guna tanah (kepadatan penduduk) di kawasan kajian yang merupakan kawasan pertanian yang terletak di kawasan bertopografi rendah juga menyumbang kepada kerentanan kawasan kajian. Topografi (ketinggian) kawasan akan memberi impak kepada berapa jauh gelombang tsunami boleh sampai ke daratan atau jarak inundasi tsunami. Selain itu, faktor jarak kawasan dari garisan pantai (shoreline) terutamanya kurang dari $10 \mathrm{~m}$ turut memberi kesan terhadap output peta risiko kerentanan tsunami yang dihasilkan. Hasil kajian ini juga diharap dapat membantu pihak yang bertanggungjawab dalam menghasilkan keputusan yang lebih baik dalam persediaan dan mitigasi bencana tsunami. Memandangkan bencana tsunami tidak dapat dijangka, penyelidik berharap agar semua pihak lebih bersedia pada masa akan datang bagi mengurangkan kesan bencana ini terhadap manusia dan juga alam sekitar. Di samping itu juga, diharap kajian ini menjadi titik tolak untuk penyelidikan secara berterusan dan penghasilan peta risiko tsunami yang lebih tepat iaitu dengan mengambil kira parameter kerentanan tsunami yang lain seperti faktor sosio-ekonomi merujuk kepada demografi penduduk, tahap pendidikan dan jenis pekerjaan (Kappes et al. 2012). Oleh kerana faktor yang mempengaruhi risiko tsunami berubah seiring dengan masa seperti perubahan populasi penduduk, perubahan guna tanah serta pembinaan struktur baru, penilaian secara berterusan perlu dilaksanakan untuk kajian akan datang.

\section{PENGHARGAAN}

Penulis ingin merakamkan setinggi-tinggi penghargaan kepada Universiti Tun Hussein Onn Malaysia dan Pejabat Penerbit UTHM atas sumbangan kewangan melalui Dana Penerbitan E15216 yang diberikan untuk penerbitan makalah ini.

\section{RUJUKAN}

Aguirre Ayerbe, I., Martinez Sanchez, J., Aniel-Quiroga Zorrilla, Í., González-Riancho, P., Merino González-Pardo, M., AlYahyai, S., González Rodríguez, E.M. \& Medina Santamaría, R. 2018. From tsunami risk assessment to disaster risk reduction the case of Oman. Natural Hazards and Earth System Sciences 18(8): 2241-2260.

Carayannis, G.P. 2002. Evaluation of the threat of mega tsunami generation from postulated massive slope failures of island strato volcanoes on La Palma, Canary Islands, and on the 
island of Hawaii. Science of Tsunami Hazards 20(5): 251-277.

Chaturvedi, S.K., Srivastava, P.K. \& Guven, U. 2017. A brief review on tsunami early warning detection using BPR approach and post analysis by SAR satellite dataset. Journal of Ocean Engineering and Science 2(2): 83-89.

Cho, M., Shin, S., Yoon, H.D. \& Cox, D.T. 2017. Numerical simulation of tsunami force acting on vertical walls. Journal of Coastal Research 79: 289-293.

Dall'Osso, F., Bovio, L., Cavalletti, A., Immordino, F., Gonella, M. \& Gabbianelli, G. 2010. A novel approach (the CRATER method) for assessing tsunami vulnerability at the regional scale using ASTER imagery. Italian Journal of Remote Sensing 42(2): 55-74.

Daud, M.E., Sagiya, T., Kimata, F. \& Kato, T. 2008. Longbaseline quasi-real time kinematic GPS data analysis for early tsunami warning. Earth, Planets and Space 60(12): 1191-1195.

ESRI. 2000. Challenges for GIS in Emergency Preparedness and Response, An ESRI White Paper. US: Environmental Systems Research Institute (ESRI).

Hebenstreit, G.T. 2001. Tsunami Research at the End of a Critical Decade. Netherlands: Springer.

Intergovernmental Oceanographic Commission. 2009. Tsunami Risk Assessment and Mitigation for the Indian Ocean; Knowing your Tsunami Risk - and What to do About It. Paris: Intergovernmental Oceanographic Commission.

Ismail, H., Abd Wahab, A.K., Mohd Amin, M.F., Mohd Yunus, M.Z., Jaffar Sidek, F. \& Esfandier, J.B. 2013. A 3-tier tsunami vulnerability assessment technique for the north-west coast of Peninsular Malaysia. Natural Hazards 63(2): 549-573.

JPS. 2005. Laporan Penyiasatan Pasca-Tsunami. Malaysia: Jabatan Pengairan dan Saliran Malaysia (JPS).

John, W. \& Kathie, W. 1997. How Earthquakes Happen. US: United State Geological Survey.

Kappes, M.S., Papathoma-Koehle, M. \& Keiler, M. 2012. Assessing physical vulnerability for multi-hazards using an indicator-based methodology. Applied Geography 32 (2): 577-590.

Komoo, I. 2005. Bencana Tsunami 26.12.04 Di Malaysia: Kajian Impak Alam Sekitar, Sosio-ekonomi dan Kesejahteraan Masyarakat. Malaysia: Institut Alam Sekitar dan Pembangunan (LESTARI) \& Akademi Sains Malaysia.

Majlis Keselamatan Negara (2005). Arahan Majlis Keselamatan Negara No. 20: Dasar dan Mekanisma Pengurusan Bencana, Malaysia. Malaysia: Majlis Keselamatan Negara.

Najihah, R., Effendi, D.M., Hairunnisa, M.A. \& Masiri, K. 2014. Tsunami vulnerability assessment mapping for the west coast of Peninsular Malaysia using a geographical information system (GIS). In IOP Conference Series: Earth and Environmental Science 18(1).

Papathoma, M., Dominey-Howes, D., Zong, Y. \& Smith, D. 2003. Assessing tsunami vulnerability, an example from Herakleio, Crete. Natural Hazards and Earth System Science 3(5): 377-389.

Paulatto, M., Pinat, T. \& Romanelli, F. 2007. Tsunami hazard scenarios in the Adriatic Sea domain. Natural Hazards and Earth System Science 7(2): 309-325.

Rantanen, H.T. 1998. GIS in Emergency Management. Prehospital and Disaster Medicine 13(S1): S19.
Sauti, N.S., Daud, M.E. \& Kaamin, M. 2020. Construction of an integrated social vulnerability index to identify spatial variability of exposure to seismic hazard in Pahang, Malaysia. International Journal of Design \& Nature and Ecodynamics 15(3): 365-372.

Setyonegoro, W. 2011. Tsunami numerical simulation Applied to tsunami early warning system along Sumatra region. Jurnal Meteorologi dan Geofisika 12(1): 21-32.

Sinaga, T.P., Nugroho, A., Lee, Y.W. \& Suh, Y. 2011. GIS mapping of tsunami vulnerability: Case study of the Jembrana Regency in Bali, Indonesia. KSCE Journal of Civil Engineering 15(3): 537-543.

Teh, S.Y., Koh, H.L., Moh, Y.T., DeAngelis, D.L. \& Jiang, J. 2011. Tsunami risk mapping simulation for Malaysia. WIT Transactions on the Built Environment 119: 3-14.

Tomaszewski, B. 2020. Geographic Information System (GIS) for Disaster Management. New York: Tailor \& Francis Group.

US Department of Energy 2002. Vulnerability Assessment Methodology, Electric Power Infrastructure. United State: US Department of Energy.

USGS 2012. Earthquake Hazards Program. United States: United States Geological Survey (USGS).

Van Westen, C.J. 2013. Remote sensing and GIS for natural hazards assessment and disaster risk management. Treatise on Geomorphology 3: 259-298.

Watts, P., Grilli, S.T., Kirby, J.T., Fryer, G.J. \& Tappin, D.R. 2003. Landslide tsunami case studies using a Boussinesq model and a fully nonlinear tsunami generation model. Natural Hazards and Earth System Sciences 3(5): 391-402.

Noor Suhaiza Sauti \& Mohd Effendi Daud

Fakulti Kejuruteraan Awam dan Alam Bina

Universiti Tun Hussein Onn Malaysia

86400 Batu Pahat, Johor Darul Takzim

Malaysia

Noor Suhaiza Sauti

Jabatan Pendidikan Politeknik dan Kolej Komuniti (JPPKK)

Kementerian Pendidikan Malaysia

61200 Putrajaya, Wilayah Persekutuan

Malaysia

Masiri Kaamin*

Neo Environmental Technology

Pusat Pengajian Diploma

Universiti Tun Hussein Onn Malaysia

84600 Panchor, Johor Darul Takzim

Malaysia

Najihah Remali

MCS Management Sdn Bhd

40460 Shah Alam, Selangor

Malaysia

*Pengarang untuk surat-menyurat; email: masiri@uthm.edu.my

Diserahkan: 30 September 2019

Diterima: 18 September 2020 